\title{
Genetic variability studies of some quantitative traits in cowpea (vigna unguiculata 1 . [walp.] ) under water stress
}

\author{
${ }^{1}$ Magashi A. I., ${ }^{2}$ Fagwalawa L.D. and ${ }^{3}$ Ibrahim M. B.
}

\begin{abstract}
A research was conducted to study genetic variability of some quantitative traits in varieties of cowpea (Vigna unguiculata L. [Walp.]) under water stressed from Zaria, Nigeria. Seeds of seven varieties of cowpea (Sampea 1, Sampea 2, IAR1074, Sampea 7, Sampea 8, Sampea 10 and Sampea 12) collected from Institute for Agricultural Research (IAR), Samaru, Zaria were screened for water stressed tolerance. The seeds were then sown in poly bags containing sandy-loam arranged in Completely Randomized Design with three replications for quantitative traits evaluation. The nutritional composition of the seeds obtained from the water stress tolerant varieties of cowpea were analyzed. The result obtained revealed highly significant difference $(\mathrm{P} \leq 0.01)$ in the effects of water stress on the number of wilted and dead plants at 40 days after sowing (DAS) and significant $(\mathrm{P} \leq 0.05) 34$ DAS. However, sampea 10 has the highest mean performance in terms of number of wilted plants at 34 DAS while sampea 2 and IAR 1074 has the lowest mean performance. However sampea 7 was found to have the highest mean performance for the number of wilted plants at 40 DAS and sampea 2 is lowest. The result for quantitative traits study indicated highly significant difference $(\mathrm{P} \leq 0.01)$ in the plant height, number of days to $50 \%$ flowering, number of days to maturity, number of pods per plant, pod length, number of seeds per plant and 100 seed weight; and significant $(\mathrm{P} \leq 0.05)$ at seedling height and number of branches per plant. Similarly, IAR1074 was found to have high performance in terms of most of the quantitative traits under study. However, sampea 8 has the highest mean performance at nutritional level. It was therefore concluded that, all the seven cowpea genotypes were water stress tolerant and produced considerable yield that contained significant nutrients. It was recommended that IAR1074 should be grown for yield while sampea 8 should be grown for protein supplements.
\end{abstract}

Keywords: cowpea, genetic variability, quantitative traits, and water stress

\footnotetext{
${ }^{1}$ Department of crop science, Faculty of Agriculture and Agricultural

${ }^{2}$ Department of Biology Kano University of Science and Technology, Wudil, Kano State.

${ }^{3}$ Department of Biology Ahmadu Bello Universiity Zaria

Corresponding author: Magashi A. I Department of Crop Science, Kano University of Science and Technology, Wudil, Kano State, Nigeria. Email magashi2@yahoo.com. Mobile phone: +2348023627191 and $+2348037173580$
} Technology,

\section{INTRODUCTION}

One of the major global challenges of the millennium is food security and how to address the phenomenon of malnutrition among the teeming and ever rising population of poor rural dwellers of the third world countries. In the wake of climate changes, fluctuating global economy and intensification of low-input agricultural production which has led to a rapid increase in soil degradation and nutrient depletion in many parts of sub-Saharan Africa, constituting serious threats to food production and food security, there is need to promote crops that could fix into global nutrient requirements. One of such crop is cowpea. As a legume grain, cowpea is an important source of human dietary protein and calories.

Cowpea production is faced with a number of constraints which are biotic and a biotic that resulted into low grain and fodder yield. In most West African countries, development and release of improved varieties that adapts well and yield better have been slow in getting to the farmers (FAO, 2000). Development of cultivars with early maturity, acceptable grain quality, resistance to diseases and pests is necessary to overcome the ever growing food shortage (Ehlers and Hall, 1997). Hence, there is need to generate more information on variability among the existing germplasm and cultivars and also broadening the gene pool of the crop for selection and development of more improved varieties not just in yield but with better nutritional values.

The study of variability and diversity in accessions of cultivated crops could provide vital information for the establishment of breeding programme, especially when intraspecific hybridization are necessary for the incorporation of new features or for mapping purposes. Assessment of genetic diversity and variability in cowpea would enhance development of cultivars for adaptation to specific production constrain. Therefore, sufficient information is necessary on genetic variability among the available germplasm to formulate and accelerate breeding programme. Previous workers have reported on genetic variability among different varieties of cowpea (Omoigu et al,. 2006; Nwosu et al., 2013) and a number of reports on the nutrient analysis (Henshaw, 2008; Mamiro et al., 2011; Odedeji and Oyeleke, 2011). However, only few of these reports compared nutrient composition of different varieties and in particular the early maturing varieties.

In order to achieve a successful breeding programme to improve the yield potentials of the crop, the quality of the grains in term of its nutritional values should also be a pivot 
concern. This enables the breeder to operate selection efficiently and subsequently developed appropriate breeding strategies to solve the problems of poor yield as well as improve the nutritive quality of the crop. Effort was made to examine the genetic differences among the studied cultivars to group them into relatively homogenous groups of baseline parents for breeding purposes.

The aim of the study is to assess the genetic variability among Screened Water Stressed tolerant varieties of cowpea for improved quantitative traits in northern Guinea savannah zone of Nigeria.

\section{MAterials AND METHODS}

\section{A. Study Area}

The experiment was conducted under screen house in the Department of Biological Sciences, Ahmadu Bello University, Zaria ( lat : $11^{0}, 21^{1} \mathrm{~N}$ and long : $7^{0}, 37^{1} \mathrm{E}$, Alt: $550-700 \mathrm{~m}$ above sea level).

\section{B. Sources of Materials}

The experimental seeds were obtained from the cowpea unit of Institute of Agricultural Research (IAR), Samaru, Ahmadu Bello University, Zaria.

\section{Screening for water stress.}

The screening for water stress was conducted using box screening method in a completely randomized design (CRD) with three replications in a screen house. The box was half filled with a soil in a ratio of 1:1 of top soil and humus, it was watered to sufficiently moist it for planting, and two seeds were sown per hole. The watering continued regularly up to three weeks after sowing where a complete withdrawal of the water was applied. The data collected at 28 days after sowing, 34 days after sowing and 40 days after sowing were the number of wilted plants, number of dead plants and the number of healthy plants.

\section{Pot experiment for growth and yield}

Polythene bag was used in place of pot and were filled with a soil in a ratio of 1:1 humus and top soil, it was watered sufficiently moist it for planting, and were arranged in completely randomize design with three replications four seeds were planted in each polythene pot and watered regularly up to harvesting. The data collected include; Germination percent, Seedling height $(\mathrm{cm})$,Plant height at maturity $(\mathrm{cm})$,Number of branches per plant, Number of leaves per plant, Leaf area, number of days to fifty percent flowering, number of days to maturity, Number of pods per plant, Pod length , number of seeds per pod, 100 seed weight and a dry weight of the plant.

\section{E. Data Analysis}

All the data collected were subjected to analysis of variance (ANOVA) with Duncan's Multiple Range Test (DMRT) used to separate the means. All tests of relationships were done using Pearson's Product Moment Correlation Coefficient.

\section{RESULTS}

The result for the analysis of variance obtained due to the exposure of seven different cowpea varieties to water stress was presented in Table 1. The result indicated a highly significant difference $(\mathrm{P} \leq 0.01)$ in the effects of water stress on the number of wilted and dead plants at 40 days after sowing (DAS). Similar result was obtained in the number of healthy plants. But a significant difference was $(\mathrm{P} \leq 0.05)$ was found in the number of wilted plants at 34 DAS. While no significant difference was found in the effects of water stress from 28 DAS to 34 DAS in the remaining parameters. Furthermore no significant difference was found in the interaction off the varieties to water level.

However, Table 2 showed the results of the mean performance of the seven cowpea varieties to water stress. The result showed that sampea 10 has the highest mean performance in terms of number of wilted plants at 34 DAS while sampea 2 and IAR 1074 has the lowest mean performance. However sampea 7 was found to have the highest mean performance for the number of wilted plants at 40 DAS and sampea 2 is lowest. Meanwhile the number of dead plants at 40 DAS sampea 7 and sampea 10 has the highest mean performance while the lowest was found in sampea 2, 12 and IAR1074. But in the number of healthy plants sampea 1 showed high mean performance while sampea 7 has the lowest mean performance. At 34 DAS sampea 12 was found to be the highest.

The combine ANOVA of the mean performance for seven cowpea genotypes to water stress was presented in table 3 . High mean performance was found in the water stressed plants for the number of wilted plants at 40 DAS while the lowest mean performance was found in the number of wilted plants at 34 DAS. But number of dead plants at 40 DAS a high mean performance was found. While in the un stressed plants the high mean performance was found in the number of wilted plants at 40 DAS and the lowest was obtained in the number of dead plants at 34 DAS. Similarly a high mean performance was found in the water stressed healthy plants while the lowest was found in the un stressed healthy plants.

The results for the relationships between the seven cowpea varieties to water stress was presented in table 4: the result indicated that positive relationship $(\mathrm{P} \leq 0.05)$ exist between the number of wilted plants at 40 DAS and number of wilted plants at 34 DAS. Also positive relationships exist between number of dead plants at 40 DAS and the number of wilted plants at 40 DAS. But negative relationship was fund in the number of healthy plants and number of wilted plants at 34 DAS, also between number of wilted plants at 40 DAS and number of dead plants at 40 DAS. However no significant relationship was found in the remaining.

Table 5 showed the results of analysis of variance for genetic variability for growth and yield of seven cowpea varieties. The result indicated that a highly significant difference $(\mathrm{P} \leq 0.01)$ was found in the plant height, number of days to $50 \%$ flowering, number of days to maturity, number of pods per plant, pod length, number of seeds per plant and 100 seed weight. While significant difference $(\mathrm{P} \leq 0.05)$ was found seedling height and number of branches per plant. No significant difference was found in the remaining. 
The mean performance of seven cowpea varieties was presented in table 6 which indicated that IAR1074 and sampea 2 has the highest mean performance in terms of germination percentage the lowest mean performance was found in sampea 8 . Similarly IAR 1074 was found to have the highest mean performance in the seedling height and least is found in sampea 10. But sampea 1 has the higher mean performance in terms of plant height and also sampea 10 is having lowest mean performance. Meanwhile the number of branches per plant the highest mean performance was obtained in sampea 10 and sampea 7 happened to be the least. In terms of number of leaves per plant the highest mean was found in sampea 1 while sampea 7 was the lowest. The highest mean performance in the leaf area was found in the sampea 7 and sampeal has lowest mean performance. However IAR1074 has the highest mean in the number of days to $50 \%$ flowering and the number of days to maturity, while sampea 7 has the higher mean performance in terms of number of pod per plant and in the pod length the high mean was found in sampea 10 similarly in the number of seeds per plants. But sampea 12 was found to have highest mean performance in 100 seed weight and sampea 1 is found to be lowest in all the yield parameters. Meanwhile sampea 1 was found to be the highest interms of dry weight and sampea 10 was having lowest mean performance.

Table 7 showed the relationships between different parameters of the seven cowpea varieties. The result indicated a positive relationship between the number of days to $50 \%$ flowering and number of days to maturity, similar relationship exist between number of days to maturity and number of pod per plant and also between number of days to $50 \%$ flowering and number of pod per plant, pod length and number of days to $50 \%$ flowering, seed per pod and number of days to 50\%flowernig, seed per pod and number of days to maturity, pod per plant and pod length a positive relationship also exist. Similarly in the result indicated that positive relationship exist between 100 seed weight and number of days to flowering, days to maturity, pod per plant, pod length and seed per pod. A positive relationship was also found between leaf area and seedling height, pod per plant and 100 seed weight. While no relationship was found germination percentage and other parameters. Similarly no relationship was found between leaf area and days to50\% flowering days to maturity.

However negative relationship was between plant and other parameters. While no relationship was in the remaining parameters.

Result for the analysis of variance of proximate analysis for seven cowpea genotypes was presented in Table 8. The result indicated a highly significant difference $(\mathrm{P} \leq 0.01)$ in the ash and protein content while a significant difference $(\mathrm{P} \leq 0.05$ ) was observed in the fibre content where as no significant difference was found in the remaining parameters. Table 9 showed the result of mean performance for the proximate analysis of seven different cowpea varieties which indicated that sampea 12 has the highest moisture content while IAR1074 is the lowest. The high ash content was found in sampea 7 and the lowest was in sampea 12. In terms of amount of fibre the highest mean performance was found in sampea 8 while IAR 1074 and sampea 12 least mean performance the lowest. However for fat content the highest mean was found in sampea 7 and the lowest was found in sampea12. Sampea 8 showed a high mean performance in terms of protein content while sampea 7 is lowest. However the carbohydrate content of cowpea varieties under study, the highest mean performance was found in IAR1074 and the lowest was found in sampea 8.

The relationship among the seven cowpea varieties for the proximate analysis was presented in table 10 which indicated that there is a negative relationship $(\mathrm{P} \leq 0.01)$ between moisture content and carbohydrate, fibre and carbohydrate and also between protein and carbohydrate while there

\section{DISCUSSION}

The screening for water stress tolerance in cowpea is a vital phenomenon that increases the potential of cowpea production in Nigeria especially in areas were drought is rampant. The significant difference and highly significant differences exhibited for number of wilted plants at 34 days and at 40 days. Number of dead plants at 40 days as well as number of healthy stands would be as an evident that values of all the growth parameters decreased with the period of growth as the water stress increased. This is in conformity with the findings of Okon (2013). The different (highest and lowest) mean performances obtained in the different varieties under water stress based on number of wilted, dead and healthy plants at different days interval could be as a result of variation that exist in the rate of decrease of growth parameters among the different varieties (in different fortnight) with respect to corresponding variation in water stresses. It was observed that, under intense water stress conditions, there was a sharp changes in the values obtained. Similar result was reported by Del Rosario et al. (2003) in soya bean seedlings.

High differences in the mean performance was observed in the different cowpea varieties to water stress at different days based on the wilted, dead and healthy plants, with the highest mean performance (8.97) obtained in the number of healthy plants and lowest (0.02) obtained in the number of dead plants at 34 days. This indicates the existence of a high degree of genetic variability in the different cowpea varieties. However, certain factors such as height of the culms, size of the leaves, the distance between the veins and the stomata openings are all affected when the varieties are developing under water stress. This is in line with findings of Ahmed and Khaliq (2007) who reported that water stress causes changes (significant difference) in the different varieties.

The positive relationships that exist between number of wilted plants at 40 days also between number of dead and wilted plants at 40 days showed that traits might not be independent in their action and are interlinked likely to bring simultaneous change for other characters. They can be effectively used as selection criteria for cowpea yields (varieties) under water stress conditions.

The negative relationships that exist between number of healthy plants and number of wilted plants at 34 days, number of wilted plants conditions can influence genetic interactions among the traits as well as genetic variance in the traits themselves. This is in line with the findings of Saro and 
Hoffman (2004) who suggested exposure to water stress conditions may induce positive relationships among the traits and expression of new gene will break negative correlations. The highly significant difference $(\mathrm{P} \leq 0.01)$ and significant difference $(\mathrm{P} \leq 0.05)$ exhibited for the characters (parameters) studied indicated the existence of sufficient genetic variability among the selected traits for improve yield in cowpea. While the non-significant difference $(\mathrm{P} \leq 0.05)$ exhibited for some few characters (parameters) is line with the report of Manggoel et al. (2012) who suggested that traits with such significant difference may be under genetic control rather than environmental influence.

The differences (highest and lowest) in mean performance of different cowpea varieties studies based on their different traits measured could be as a result of durations of the experiment which affects the differential changes that might occur in the morphological features of the varieties of the plants at a given time. The growth habits of different varieties studied also varied which result to differences in the mean performance, with highest mean performance in a particular trait such as maturity and lowest in another trait in a given variety.

This observation is in line with the findings of Agbor $e t$ al. (2012) who observed that there is variability in the growth habit of cowpea in different species.

Results from this study are similar to those found by Lobato and Costa (2011) where reduction in leaf relative to water content was reported. The study also recorded reduced vegetative growth due to water stress. This finding agrees with that of Aguyoh et al (2013). Similar results on decrease in growth and yield were reported by Aguyoh et al (2013) which can be attributed to the effects water has on the physiology of cowpea. The finding also agrees with that of Samson and Helmut (2007) on cowpea that reduction in leaf area in cowpea varieties (with sampea 1 had the lowest $34.47 \mathrm{~cm}^{2}$ ) is a mechanism adapted to avoid higher rate of transpiration and reduced surfaces for radiation due to water deficit. The reduction in number of pods result of increase in with the lowest found in sampea 10 which is (4.33) could be as a result of increase in reduction of soil moisture, thereby reducing the number of seeds which may contribute to low yield in water stressed cowpea. This is in line with the findings of who reported reduction in number of pods in different cowpea varieties Abayomi and Abidoye (2009).

The positive relationships that exist between yield traits or parameters could be as a result of the fact that cowpea varieties height studied contributed to yield as it leads to resulting increase in the number of days to maturity, days to flowering, number of pods and other yield traits. The result obtained is in tine with the findings of taking (2002) who reported that plant height contribute positively to different yield parameters or traits. Also yield improvement would be possibly achieved by selecting for the number of pods per plant, since the study revealed that, number of pods per plants increased significantly.

Correlations has used in indirect selection for breeding characters (Lyman 1993). The highly significant difference $(\mathrm{P} \leq 0.01)$ and significant difference $(\mathrm{P} \leq 0.05)$ obtained in the ash, protein content and fibre contents showed that the range of values were within the recommended values, this range of values fall within the values reported for cowpea by Duke (1931) and Longe (1980). In this study the Ash having 2-3\% protein: $20-27 \%$ and fibre $2-4 \%$.

The best mean performance of the proximate analysis were found in carbohydrate in all the cowpea varieties (58.72-65.94\%) while the least mean performances in all the varieties were found in Ash content (2-4\%). The high and low mean performance of the studied varieties may not depend on genetic factor alone, but also on environmental influences. The result obtained is in line with the findings of Nwosu et al. (2013) who worked on the different cowpea varieties and discovered high and low in the mean performance of the proximate analysis contents. However, from the result obtained high variability was found in the mean performances of the different varieties in terms of their yield traits (Ash content, protein, moisture, fibre, fat and carbohydrates). The observed variability was in agreement with the work of Nwosu et al. (2013) and could serve as an important purpose in improving the crop as selected would be effective for population with broad genetic variability as opened by previous workers (Omoigai et al., 2006; Dento and Nwangbunika, 2011).

The negative relationship that exist showed that moisture content had the highest relationship (0.63) and the least values or relationships were found in fibre and protein $(0.58)$. The significance of the result would be better interpreted to mean that the cowpea varieties cultivated under wide cultural conditions such as soil compositions climate and agronomic practices vary widely in moisture and carbohydrate, contents, followed by the fibre and protein. These components are important in determining nutritive quality and processing quality of cowpea seeds. The content of fat was the least with no relationship. The non-relationship that exist between fat content and carbohydrate is an advantage during processing to flour, since unlike other legumes such as soya bean, there is no need for a defatting stage in flour production. Similar finding was obtained by Henshaw (2008) who studied varietal differences in physical characteristics and proximate composition of cowpea (vigna unguiculata).

\section{REFERENCES}

[1] Ba FS, Pasquet RE, Gepts P (2004) Genetic diversity in cowpea [Vigna unguiculata (L.) Walp.] asrevealed by RAPD markers. Genet Resource Crop Evol 51:539-550

[2] Barone A, del Guidice A, Ng NQ (1992) Barriers to interspecific hybridization in $V$. unguiculata and $V$. vexillata. Sexual Plant Reproduction 5:195-200

[3] Baudoin JP, Maréchal R (1985) Genetic diversity in Vigna. In: Singh SR, Rachie KO (eds) Cowpea

[4] Bressani R (1985) Nutritive value of cowpea. In: Singh SR, Rachie KO (eds) Cowpea Research,Production and Utilization. John Wiley and Sons, Ltd., Chichester, NY, pp. 353-359

[5] Carsky RJ, Vanlauwe B, Lyasse O (2002) Cowpea rotation as a resource management technology for cereal-based systems in the savannas of West Africa. In: Fatokun CA, Tarawali SA,Singh BB, Kormawa PM, M Tamo (eds) Challenges and Opportunities for Enhancing Sustainable Cowpea Production. International Institute of Tropical Agriculture, Ibadan, Nigeria, pp. 252-266

[6] Coulibaly S, Pasquet RS, Papa R, Gepts P (2002) AFLP analysis of the phenetic organization and genetic diversity of cowpea [Vigna unguiculata (L.)Walp.] reveals extensive gene flow between wild and domesticated types. Theor Appl Genet 104:258-266 
[7] Craufurd PQ, Summerfield RJ, Ell RH, Roberts EH (1997) Photoperiod, temperature and the growth and development of cowpea (Vigna unguiculata). In: Singh BB, Mohan Raj DR, Dashiell KE, Jackai LEN (eds) Advances in Cowpea Research. Copublication Intl Inst Tropical Agric (IITA) and Japan Intl Res Center Agric Sci (JIRCAS). Sayce, Devon, UK, pp. 75-86

[8] Daoust RA, Roberts DW, Das Neves BP (1985) Distribution, biology and control of cowpea pests in Latin America. In: Singh SR, Rachie KO (eds) Cowpea Research, Production and Utilization. John Wiley and Sons, Ltd., Chichester, NY, pp. 249-264

[9] Duivenbooden Van H, Abdoussalam S, Mohamed AB (2002) Impact of climate change on agricultural production in the Sahel-Part 2. Case study for groundnut and cowpea in Niger. ClimateChange 54:349-368

[10] Diouf, D. (2011). Recent advances in cowpea (Vigna unguiculata (L). Walp). Omics Research for Genetic Improvement, African Journal of Biotechnology. 10: 2803-2810.

[11] Ehlers, J.D. and Hall, A.E. (1997).Cowpea (VignaunguiculataL. Walp), Field Crops Research.53: 187 - 204

[12] FAO. (2000). The state of food insecurity in the world (SOFI) Rome. Italy: FAO-UN. www.fao. org/FOCUS/E/SOFI00/sofi001-e.htm Accessed on March 12th, 2014.

[13] FAO.(2004). http//www.fao.stat.fao.orgAccessed of 12th March, 2014.

[14] Geissler, P.W., Mwaniki, D.L., Thiong'o, F., Michaelsen, K.F. and Friis, H.(1998). Geophagy, iron status and anemia among primary school children in Western Kenya,Tropical Medicine and International Health. 3(7): 529-534

[15] Hall, A.E.,Cisse, N., Thiaw, S., Elawad, H.O.A. and Ehlers, J.D. (2003). Development of cowpea cultivars and germplasm by Bean/Cowpea CRSP,Field Crop Research. 82:103-134.

[16] Henshaw, F.O. (2008). Varietal differences in physical characteristics and proximate composition of cowpea (Vigna unguiculata),World Journal of Agricultural Sciences. 4(3): 302-306.

[17] Mamiro, P.S., Mbwaga, A.M., Mamiro, D.P., Nmanri, A.W. and Kinabo, J.L. (2011).Nutritional quality and utilization of local and improved cowpea varieties in some regions in Tanzania, African Journal of Food, Agriculture, Nutrition and Development. 11(1): 44904506.

[18] Mortimore, M.J., Singh, B.B., Harris, F. and Blade, S.F. (1997). Cowpea in traditional cropping systems. In:Advances in cowpea research. Singh, B. B., Mohan Raj, D. R.., Dashiell, K.E. and Jackai, L.E.N. (Eds.). Co - Publication of IITA and JIRCAS. IITA, Ibadan, Nigeria. 99-113.

[19] Nielson, S., Ohler, T. and Mitchell, C. (1997). Cowpea leaves for human consumption: production, utilization and nutrient composition. In: Singh, S.R. and Rachie, K.O. (eds.).Cowpea researches, production and utilization. Wiley, New York. 145-162.

[20] Nwofia, G.E., Nwanebu, M and Agbo, C.U. (2012). Variability and inter-relationship between yield and associated traits in cowpea (Vigna unguiculata L. Walp) as influenced by plant population, World Journal of Agricultural Sciences. 8(4): 396-402.

[21] Nwosu, D.J., Olatunbosun, B.D and Adetiloye, I.S. (2013). Genetic variability, heritability and genetic advance in cowpea genotypes in two agro-ecological environments, Greener Journal of Biological Science. 3(5): 202-207.

[22] Odedeji, J.O. and Oyeleke, W.A (2011). Proximate, physiochemical and organoleptic properties of whole and dehulled cowpea seed flour (Vigna unguiculata), Pakistan Journal of Nutrition. 10 (12): 11751178.

[23] Omoigui, L.O., Ishiyaku. M.F., Kamara, A.Y., Alabi, S.O. and Mohammed, S.G. (2006). Genetic variability and heritability studies of some reproductive traits in cowpea [Vigna unguiculata (L.) Walp.],African Journal of Biotechnology. 5 (13):1191-1195.

[24] Oritz, R. (1998). Cowpeas From Nigeria: a silent food revolution, Outlook on Agriculture. 27 (2): 125 - 128.

TABLE I:

Mean SQuares For Water StRess Tolerance ScReening Of SEVEn DifFerent CowPea GenotyPes.

\begin{tabular}{|c|c|c|c|c|c|c|c|c|}
\hline Sources of variations & Df & $\begin{array}{l}\text { Number of } \\
\text { wilted plants } \\
28 \text { DAS }\end{array}$ & $\begin{array}{l}\text { Number of } \\
\text { dead plants } \\
28 \text { DAS }\end{array}$ & $\begin{array}{l}\text { Number of } \\
\text { wilted plants } \\
34 \text { DAS }\end{array}$ & $\begin{array}{l}\text { Number of } \\
\text { dead plants } \\
34 \text { DAS }\end{array}$ & $\begin{array}{l}\text { Number of } \\
\text { wilted plants } \\
\text { 40 DAS }\end{array}$ & $\begin{array}{l}\text { Number of } \\
\text { dead plants } \\
\text { 40 DAS }\end{array}$ & $\begin{array}{l}\text { Number of healthy } \\
\text { plants }\end{array}$ \\
\hline Variety & 6 & $0.00^{\mathrm{ns}}$ & $0.00^{\mathrm{ns}}$ & $0.21^{\mathrm{ns}}$ & $0.02^{\mathrm{ns}}$ & $1.22^{*}$ & $0.21^{\mathrm{ns}}$ & $1.52^{\mathrm{ns}}$ \\
\hline Water level & 1 & $0.00^{\mathrm{ns}}$ & $0.00^{\mathrm{ns}}$ & $6.72^{*}$ & $0.00^{\mathrm{ns}}$ & $10.89^{* * *}$ & $6.72^{* *}$ & $72.00^{* *}$ \\
\hline $\begin{array}{l}\text { Variety and water } \\
\text { level }\end{array}$ & 2 & $0.00^{\mathrm{ns}}$ & $0.00^{\mathrm{ns}}$ & $0.06^{\mathrm{ns}}$ & $0.00^{\mathrm{ns}}$ & $0.06^{\mathrm{ns}}$ & $0.06^{\mathrm{ns}}$ & $0.17^{\mathrm{ns}}$ \\
\hline Error & 32 & 0.00 & 0.00 & 0.92 & 0.03 & 1.09 & 0.92 & 7.34 \\
\hline
\end{tabular}

TABLE II:

MEAN PERFORMANCE OF SEVEN COWPEA VARIETIES UNDER WATER STRESS.

\begin{tabular}{|c|c|c|c|c|c|c|c|}
\hline Variety & $\begin{array}{lr}\text { No of } & \text { Wilted } \\
\text { Plants } & (28 \\
\text { DAS }) & \\
\end{array}$ & $\begin{array}{lr}\text { No of } & \text { Dead } \\
\text { Plants } & (28 \\
\text { DAS }) & \\
\end{array}$ & $\begin{array}{lr}\text { No of wilted } \\
\text { Plants } \\
\text { DAS) }\end{array}$ & $\begin{array}{lr}\text { No of } & \text { Dead } \\
\text { Plants } & (34 \\
\text { DAS }) & \\
\end{array}$ & $\begin{array}{l}\text { No of Wilted } \\
\text { Plants } \quad(40 \\
\text { DAS })\end{array}$ & $\begin{array}{lr}\text { No of } & \text { Dead } \\
\text { Plants } & (40 \\
\text { DAS }) & \\
\end{array}$ & $\begin{array}{l}\text { No of } \\
\text { HealthyPlants }\end{array}$ \\
\hline Sampeal & $0.00^{\mathrm{a}}$ & $0.00^{\mathrm{a}}$ & $0.50^{\mathrm{b}}$ & $0.00^{\mathrm{a}}$ & $0.83^{\mathrm{d}}$ & $0.50^{\mathrm{d}}$ & $10.17^{\mathrm{a}}$ \\
\hline Sampea2 & $0.00^{\mathrm{a}}$ & $0.00^{\mathrm{a}}$ & $0.67^{\mathrm{c}}$ & $0.00^{\mathrm{a}}$ & 0.67 & $0.67^{\mathrm{c}}$ & $10.00^{\mathrm{a}}$ \\
\hline IAR1074 & $0.00^{\mathrm{a}}$ & $0.00^{\mathrm{a}}$ & $0.67^{\mathrm{c}}$ & $0.00^{\mathrm{a}}$ & $0.83^{\mathrm{d}}$ & $0.67^{\mathrm{c}}$ & $9.83^{\mathrm{b}}$ \\
\hline Sampea7 & $0.00^{\mathrm{a}}$ & $0.00^{\mathrm{a}}$ & $1.00^{\mathrm{a}}$ & $0.00^{\mathrm{a}}$ & $1.67^{\mathrm{a}}$ & $1.00^{\mathrm{a}}$ & $8.83^{\mathrm{d}}$ \\
\hline Sampea8 & $0.00^{\mathrm{a}}$ & $0.00^{\mathrm{a}}$ & $0.83^{\mathrm{b}}$ & $0.00^{\mathrm{a}}$ & $1.00^{\mathrm{b}}$ & $0.83^{\mathrm{b}}$ & $9.33^{\mathrm{c}}$ \\
\hline Sampea10 & $0.00^{\mathrm{a}}$ & $0.00^{\mathrm{a}}$ & $1.00^{\mathrm{a}}$ & $0.00^{\mathrm{a}}$ & $1.00^{\mathrm{b}}$ & $1.00^{\mathrm{a}}$ & $9.00^{\mathrm{c}}$ \\
\hline Sampea12 & $0.00^{\mathrm{a}}$ & $0.00^{\mathrm{a}}$ & $0.67^{\mathrm{c}}$ & $0.17^{\mathrm{a}}$ & $1.00^{\mathrm{b}}$ & $0.67^{\mathrm{c}}$ & $9.50^{\mathrm{b}}$ \\
\hline Means & 0.00 & 0.00 & 0.76 & 0.02 & 0.93 & 0.76 & 9.52 \\
\hline $\mathrm{SE}(+-)$ & 0.00 & 0.00 & 0.36 & 0.06 & 0.39 & 0.36 & 1.02 \\
\hline
\end{tabular}

Key: $a=$ higher mean followed by $b, c$, and $d$ is the lowest mean 
TABLE III

MEAN PERFORMANCE OF (COMBINED ANOVA) OF THE SEVEN COWPEA GENOTYPES.

\begin{tabular}{|l|l|l|l|l|l|l|l|}
\hline Water level & NWP 28 DAS & NDP28 DAS & NWP 34 DAS & NDP34 DAS & NWP 40 DAS & NDP 40 DAS & NHP \\
\hline Water stressed & $0.00^{\mathrm{a}}$ & $0.00^{\mathrm{a}}$ & $1.22^{\mathrm{a}}$ & $0.03^{\mathrm{a}}$ & $1.56^{\mathrm{a}}$ & $1.22^{\mathrm{a}}$ & $9.94^{\mathrm{a}}$ \\
\hline Control & $0.00^{\mathrm{a}}$ & $0.00^{\mathrm{a}}$ & $0.64^{\mathrm{a}}$ & $0.00^{\mathrm{a}}$ & $0.76^{\mathrm{b}}$ & $0.64^{\mathrm{b}}$ & $8.00^{\mathrm{b}}$ \\
\hline Means & 0.00 & 0.00 & 0.93 & 0.02 & 1.94 & 0.93 & 8.97 \\
\hline S E $( \pm)$ & 0.00 & 0.00 & 0.89 & 0.00 & 0.41 & 0.71 & 0.89 \\
\hline
\end{tabular}

Key: $a=$ highest mean and $b=$ lowest mean

TABLE IV:

RELATIONSHIPS AMONG THE WILTED AND DEAD PLANTS AT DIFFERENT TIME OF WATER STRESS OF THE SEVEN COWPEA GENOTYPE

\begin{tabular}{|c|c|c|c|c|c|c|c|}
\hline & $\begin{array}{l}\text { No of Wilted } \\
\text { Plants( } 28 \\
\text { DAS })\end{array}$ & $\begin{array}{l}\text { No of Dead } \\
\text { Plants }(28 \\
\text { DAS })\end{array}$ & $\begin{array}{l}\text { No of } \\
\text { Wilted } \\
\text { Plants(34 } \\
\text { DAS) }\end{array}$ & $\begin{array}{l}\text { No of Dead } \\
\text { Plants( } 34 \\
\text { DAS) }\end{array}$ & $\begin{array}{l}\text { No of } \\
\text { Wilted } \\
\text { Plants(40 } \\
\text { DAS) }\end{array}$ & $\begin{array}{l}\text { No of Dead } \\
\text { Plants }(40 \\
\text { DAS })\end{array}$ & $\begin{array}{l}\text { No of } \\
\text { Healthy } \\
\text { Plants }\end{array}$ \\
\hline NWP 28 & 1.00 & & & & & & \\
\hline NDP 28 & 0.00 & 1.00 & & & & & \\
\hline NWP 34 & 0.00 & 0.00 & 1.00 & & & & \\
\hline NDP 34 & 0.00 & 0.00 & $0.20^{\mathrm{ns}}$ & 1.00 & & & \\
\hline NWP 40 & 0.00 & 0.00 & $0.65^{*}$ & $0.31^{\mathrm{ns}}$ & 1.00 & & \\
\hline NDP 40 & 0.00 & 0.00 & $1.00^{\mathrm{ns}}$ & $0.20^{\mathrm{ns}}$ & $0.65^{*}$ & 1.00 & \\
\hline NHP & 0.00 & 0.00 & $-0.95^{*}$ & $-0.31^{\mathrm{ns}}$ & $-0.85^{*}$ & $-0.95^{*}$ & 1.00 \\
\hline
\end{tabular}

Key: $\mathrm{ns}=$ no significant difference $*=$ significant difference $(\mathrm{P} \leq 0.05) * *=$ Highly significant difference $(\mathrm{P} \leq 0.01)$

TABLE V:

MEAN SQUARE FOR THE GENETIC VARIABILITY STUDIES AMONG SEVEN COWPEA VARIETY

\begin{tabular}{|c|c|c|c|c|c|c|c|c|c|c|c|c|c|c|}
\hline SV & Df & G7 & $\begin{array}{l}\text { SH } \\
(\mathrm{cm})\end{array}$ & $\mathrm{PH}(\mathrm{cm})$ & $\mathrm{B} / \mathrm{p}$ & $\mathrm{L} / \mathrm{p}$ & LA & D 50\% F & DM & $\mathrm{P} / \mathrm{p}$ & $\mathrm{Pl}(\mathrm{cm})$ & $S / p$ & SW & DW (g) \\
\hline $\begin{array}{l}\text { Vari } \\
\text { ety }\end{array}$ & 6 & $\begin{array}{l}1.4 \\
9^{\text {ns }}\end{array}$ & $13.43^{*}$ & $749.34 * *$ & $\begin{array}{l}2.74 \\
*\end{array}$ & $27.11^{\mathrm{n}}$ & $\begin{array}{l}154.59 \\
\text { ns }\end{array}$ & $\begin{array}{l}3679.56 * \\
*\end{array}$ & $\begin{array}{l}6727.89 \\
* *\end{array}$ & $\begin{array}{l}15.75^{*} \\
*\end{array}$ & $82.15^{* *}$ & $47.60 * *$ & $144.96^{* * *}$ & $52.44 * *$ \\
\hline $\begin{array}{l}\text { Erro } \\
r\end{array}$ & 14 & $\begin{array}{l}2.0 \\
0\end{array}$ & 4.85 & 73.98 & 0.95 & 14.57 & 89.38 & 3.09 & 2.24 & 1.95 & 1.63 & 0.95 & 0.19 & 1.24 \\
\hline
\end{tabular}

Key: ns $=$ No significant difference $*$ Significant difference $(\mathrm{P} \leq 0.05) * *=$ Highly significant difference $(\mathrm{P} \leq 0.01)$

TABLE VI:

MEAN PERFORMANCE OF THE SEVEN COWPEA GENOTYPES FOR GROWTH AND YIELD

\begin{tabular}{|c|c|c|c|c|c|c|c|c|c|c|c|c|c|}
\hline Variety & G\% & $\mathrm{SH}(\mathrm{cm})$ & $\begin{array}{l}\mathrm{PH} \\
(\mathrm{cm})\end{array}$ & $\mathrm{B} / \mathrm{P}$ & $\mathrm{L} / \mathrm{P}$ & LA & $\begin{array}{l}\mathrm{D} \\
50 \% \mathrm{~F}\end{array}$ & DM & $\mathrm{P} / \mathrm{P}$ & P L & $S / p$ & $100 \mathrm{SW}$ & DW \\
\hline Sampea1 & $11.33^{\mathrm{a}}$ & $32.40^{\mathrm{bc}}$ & $91.00^{\mathrm{a}}$ & $6.00^{\mathrm{bc}}$ & $19.33^{\mathrm{a}}$ & $34.47^{b}$ & $0.00^{\mathrm{d}}$ & $0.00^{\mathrm{e}}$ & $0.00^{\mathrm{c}}$ & $0.00^{\mathrm{d}}$ & $0.00^{\mathrm{e}}$ & $0.00^{f}$ & $16.90^{2}$ \\
\hline Sampea2 & $11.00^{\mathrm{a}}$ & $36.23^{\text {ba }}$ & $67.33^{\mathrm{b}}$ & $5.33^{\mathrm{bc}}$ & $12.33^{\text {ba }}$ & $44.50^{\text {ba }}$ & $94.33^{\mathrm{a}}$ & $125.67^{\mathrm{b}}$ & $5.00^{\mathrm{ba}}$ & $12.83^{\text {ba }}$ & $10.00^{\mathrm{bc}}$ & $15.23^{\mathrm{e}}$ & $10.33^{\mathrm{t}}$ \\
\hline IAR 1074 & $11.67^{\mathrm{a}}$ & $36.63^{\mathrm{a}}$ & $71.67^{\mathrm{b}}$ & $5.67^{\mathrm{bc}}$ & $16.67^{\text {ba }}$ & $47.63^{\mathrm{ba}}$ & $96.67^{\mathrm{a}}$ & $132.00^{\mathrm{a}}$ & $5.67^{\text {ba }}$ & $14.00^{\mathrm{ba}}$ & $9.33^{\mathrm{bcd}}$ & $19.30^{\mathrm{b}}$ & $14.87^{\circ}$ \\
\hline Sampea7 & $11.33^{\mathrm{a}}$ & $36.17^{\text {ba }}$ & $70.67^{b}$ & $4.67^{\mathrm{c}}$ & $11.33^{\mathrm{b}}$ & $54.00^{\mathrm{a}}$ & $96.33^{\mathrm{a}}$ & $128.33^{\mathrm{b}}$ & $7.33^{\mathrm{a}}$ & $13.67^{\text {ba }}$ & $10.67^{\text {ba }}$ & $16.23^{d}$ & $10.73^{\mathrm{b}}$ \\
\hline Sampea8 & $09.67^{\mathrm{a}}$ & $32.30^{\mathrm{bc}}$ & $49.00^{\mathrm{cd}}$ & $7.00^{\mathrm{ba}}$ & $17.00^{\text {ba }}$ & $39.57^{\text {ba }}$ & $91.00^{\mathrm{b}}$ & $126.33^{\mathrm{b}}$ & $5.67^{\text {ba }}$ & $12.33^{\mathrm{b}}$ & $8.67^{\mathrm{cd}}$ & $16.93^{\mathrm{dc}}$ & $15.83^{\circ}$ \\
\hline Sampea10 & $10.67^{\mathrm{a}}$ & $31.73^{\mathrm{c}}$ & $43.67^{\mathrm{d}}$ & $7.33^{\mathrm{a}}$ & $12.33^{\text {ba }}$ & $39.57^{\text {ba }}$ & $86.67^{b}$ & $121.67^{\mathrm{c}}$ & $4.33^{\mathrm{b}}$ & $15.17^{\mathrm{a}}$ & $12.33^{\mathrm{a}}$ & $17.10^{\mathrm{c}}$ & $6.57^{\mathrm{c}}$ \\
\hline Sampea12 & $11.67^{\mathrm{a}}$ & $34.43^{\mathrm{bc}}$ & $59.50^{\mathrm{bc}}$ & $5.33^{\mathrm{bc}}$ & $13.67^{\text {ba }}$ & $52.23^{\mathrm{ba}}$ & $73.33^{\mathrm{c}}$ & $105.67^{\mathrm{d}}$ & $5.33^{\mathrm{ba}}$ & $8.83^{\mathrm{c}}$ & $7.67^{\mathrm{d}}$ & $21.07^{\mathrm{a}}$ & $7.17^{\mathrm{c}}$ \\
\hline Mean & 11.05 & 34.27 & 64.69 & 5.90 & 14.67 & 44.57 & 77.33 & 105.67 & 4.76 & 10.98 & 8.38 & 15.12 & 11.76 \\
\hline $\operatorname{SE}( \pm)$ & 0.51 & 1.03 & 6.28 & 0.46 & 1.62 & 3.94 & 12.55 & 1.69 & 0.93 & 1.92 & 1.46 & 2.49 & 1.54 \\
\hline
\end{tabular}

Key: a = High mean followed by b a, b, b c, c, b c d, c d, and d = lowest mean

TABLE VI:

RELATIONSHIP BETWEEN THE GROWTH AND YIELD PARAMETERS OF THE SEVEN COWPEA GENOTYPES UNDER STUDY

\begin{tabular}{|c|c|c|c|c|c|c|c|c|c|c|c|c|c|}
\hline & $\begin{array}{l}\text { Germ } \\
\%\end{array}$ & $S D H$ & $P L H$ & $B R P$ & $L V P$ & $L F A$ & $D F L$ & $D M T$ & $P P P$ & $S P P$ & $P L$ & $S W$ & $D W$ \\
\hline $\begin{array}{l}\text { Germ } \\
\%\end{array}$ & 1.00 & & & & & & & & & & & & \\
\hline SDH & 0.18 & 1.00 & & & & & & & & & & & \\
\hline PLH & 0.26 & 0.15 & 1.00 & & & & & & & & & & \\
\hline BRPP & -0.42 & -0.16 & $-0.51^{*}$ & 1.00 & & & & & & & & & \\
\hline LVPP & -0.27 & -0.16 & $-0.45^{*}$ & 0.21 & 1.00 & & & & & & & & \\
\hline LFA & 0.21 & $0.53^{*}$ & -0.13 & -0.32 & -0.44 & 1.00 & & & & & & & \\
\hline DFL & -0.09 & 0.31 & $-0.55^{*}$ & -0.06 & $0.45^{*}$ & 0.37 & 1.00 & & & & & & \\
\hline DMT & -0.09 & 0.31 & $-0.61^{* *}$ & -0.03 & -0.44 & 0.37 & $0.99^{* *}$ & 1.00 & & & & & \\
\hline PPP & -0.18 & 0.40 & -0.35 & -0.24 & -0.35 & $0.51^{*}$ & $0.88^{* *}$ & $0.81^{* *}$ & 1.00 & & & & \\
\hline PL & -0.16 & 0.23 & $-0.60^{* *}$ & 0.05 & -0.40 & 0.21 & $0.95^{* *}$ & $0.94^{* *}$ & $0.69^{* *}$ & 1.00 & & & \\
\hline SPP & -0.15 & 0.17 & $-0.66^{* *}$ & 0.08 & $-0.51^{*}$ & 0.32 & $0.92^{* *}$ & $0.92^{* *}$ & $0.70^{* *}$ & $0.94^{* *}$ & 1.00 & & \\
\hline $100 \mathrm{SW}$ & 0.01 & 0.27 & $-0.63^{* *}$ & -0.06 & -0.39 & 0.44 & $0.89^{* *}$ & $0.91^{\text {** }}$ & $0.76^{* *}$ & $0.80^{* *}$ & $0.81^{\text {** }}$ & 1.00 & \\
\hline DW & -0.14 & -0.13 & $0.48^{*}$ & -0.05 & $0.51^{*}$ & -0.27 & -0.41 & -0.42 & -0.33 & -0.43 & $\overline{-}^{-} .58^{* *}$ & $-0.54^{*}$ & 1.00 \\
\hline
\end{tabular}

Key:ns=Norelationship $*$ Relationship ${ }^{* *}=$ strongrelationship 
TABLE VII:

RESULT FOR THE MEAN SQUARES OF THE SEVEN COWPEA GENOTYPES

\begin{tabular}{|c|c|c|c|c|c|c|c|}
\hline $\begin{array}{l}\text { Sources of } \\
\text { variation }\end{array}$ & Df & Moisture & Ash & Fibre & Fat/oil & Protein & Carbohydrate \\
\hline Variety & 5 & $2.22^{\mathrm{ns}}$ & $1.54^{* *}$ & $2.10^{*}$ & $0,21^{\mathrm{ns}}$ & $12.69^{* *}$ & $21.70^{\mathrm{ns}}$ \\
\hline Error & 12 & 2.43 & 0.11 & 0.83 & 0.43 & 3.76 & 16.94 \\
\hline
\end{tabular}

Key: $n s=$ No significant difference $*=$ Significant difference $(\mathrm{P} \leq 0.05) * *=$ Highly Significant difference $(\mathrm{P} 0.01)$

TABLE IX:

MEAN PERFORMANCE OF THE PROXIMATE ANALYSIS FOR THE SIX COWPEA GENOTYPES UNDER STUDY

\begin{tabular}{|lllllll|}
\hline Variety & Moisture & Ash & Fibre & Fat/oil & Protein & Carbohydrate \\
\hline Sampea 2 & $6.67^{\mathrm{a}}$ & $2.17^{\mathrm{b}}$ & $3.00^{\mathrm{ab}}$ & $3.33^{\mathrm{a}}$ & $23.79^{\mathrm{ab}}$ & $62.29^{\mathrm{a}}$ \\
IAR 1074 & $5.00^{\mathrm{a}}$ & $2.35^{\mathrm{b}}$ & $2.33^{\mathrm{b}}$ & $3.33^{\mathrm{a}}$ & $21.05^{\mathrm{b}}$ & $65.94^{\mathrm{a}}$ \\
Sampea 7 & $6.67^{\mathrm{a}}$ & $3.97^{\mathrm{a}}$ & $4.00^{\mathrm{ab}}$ & $3.75^{\mathrm{a}}$ & $20.99^{\mathrm{b}}$ & $59.38^{\mathrm{a}}$ \\
Sampea 8 & $5.83^{\mathrm{a}}$ & $2.22^{\mathrm{a}}$ & $4.33^{\mathrm{a}}$ & $3.32^{\mathrm{a}}$ & $26.40^{\mathrm{a}}$ & $58.72^{\mathrm{a}}$ \\
Sampea 10 & $6.67^{\mathrm{a}}$ & $2.20^{\mathrm{b}}$ & $3.00^{\mathrm{ab}}$ & $3.33^{\mathrm{a}}$ & $24.10^{\mathrm{ab}}$ & $59.73^{\mathrm{a}}$ \\
Sampea 12 & $7.50^{\mathrm{a}}$ & $2.16^{\mathrm{b}}$ & $2.33^{\mathrm{b}}$ & $2.92^{\mathrm{a}}$ & $22.70^{\mathrm{ab}}$ & $62.25^{\mathrm{a}}$ \\
Mean & 6.39 & 2.51 & 3.17 & 3.33 & 23.17 & 61.39 \\
S E $( \pm)$ & 0.63 & 0.30 & 0.45 & 0.25 & 1.03 & 1.75 \\
\hline
\end{tabular}

Key: $\mathrm{a}=$ Higher mean followed by $\mathrm{ab}, \mathrm{b}=$ lowest mean

TABLE X:

RELATIONSHIP AMONG THE NUTRITIONAL CONTENT OF COWPEA.

\begin{tabular}{|lllllll|}
\hline & Moisture & Ash & Fibre & Fat/oil & Protein & Carbohydrate \\
\hline Moisture & 1.00 & & & & & \\
Ash & $0.09^{\mathrm{ns}}$ & 1.00 & & & & \\
Fibre & $0.20^{\mathrm{ns}}$ & $0.28^{\mathrm{ns}}$ & 1.00 & & & \\
Fat/oil & $0.06^{\mathrm{ns}}$ & $0.39^{\mathrm{ns}}$ & $0.21^{\mathrm{ns}}$ & 1.00 & & \\
Protein & $0.08^{\mathrm{ns}}$ & $-0.38^{\mathrm{ns}}$ & $0.24^{\mathrm{ns}}$ & $-0.11 \mathrm{~ns}$ & 1.00 & \\
Carbohydrate & $-0.63^{* *}$ & $-0.24^{\mathrm{ns}}$ & $-0.58 \mathrm{~ns}$ & $-0.21 \mathrm{~ns}$ & $-0.58^{*}$ & 1.00 \\
\hline
\end{tabular}

Key: $\mathrm{ns}=$ no relationship $*=$ relationship $* *$ strong relationship

TABLE XI:

SOME OF THE QUALITATIVE TRAITS FOUND IN THE SEVEN COWPEA VARIETIES UNDER STUDY

\begin{tabular}{|lllllll|}
\hline Variety & Growth habit & Flower color & Seed coat color & Seed shape & Seed texture & Eye color \\
\hline Sampea1 & Spreading & - & - & - & - & - \\
Sampea2 & Spreading & White & Brown & Kidney & Smooth & Brown \\
IAR1074 & Spreading & White & Brown & Kidney & Smooth & Brown \\
Sampea7 & Erect & White & Brown & Rhomboid & Smooth & Brown \\
Sampea8 & Erect & White/Violet & White & Rhomboid & Rough & Black \\
Sampea10 & Erect & White & White & Rhomboid & Rough & Black \\
Sampea12 & Spreading & White & Brown & Kidney & Smooth & Brown \\
\hline
\end{tabular}

